\title{
LEMBAGA KEUANGAN MIKRO DAN PEMBERDAYAAN PEREMPUAN SEBAGAI UPAYA PENGENTASAN KEMISKINAN DI KABUPATEN SUMEDANG
}

\author{
Layyinaturrobaniyah, Mokhamad Anwar, Sulaeman R. Nidar, dan Ida Yuliani \\ Fakultas Ekonomi dan Bisnis, Universitas Padjadjaran \\ E-mail: layyinaturrobaniyah@unpad.ac.id
}

\begin{abstract}
ABSTRAK. Lembaga keuangan mikro disebut sebagai suatu lembaga yang dapat memberikan kemudahan bagi para pengusaha kecil dan mikro dalam pemberian kredit mikro untuk melakukan pengembangan usaha serta untuk mengentaskan kemiskinan. Penelitian ini bertujuan untuk mengetahui pengaruh lembaga keuangan mikro dan pemberdayaan perempuan terhadap tingkat kemiskinan pada Orang terkena Dampak di daerah sekitar pembangunan Waduk Jatigede, Sumedang, Jawa Barat, dengan populasi sebesar 10.924 orang. Dengan metode non-probability sampling dengan teknik purposive sampling dipilih 100 orang terkena dampak pembangunan waduk Jatigede yang tersebar di lima kecamatan di Sumedang yakni Cisitu, Darmaraja, Wado, Jatigede dan Jatinunggal. Pengumpulan data dilakukan melalui pengisian kuisioner langsung kepada masyarakat OTD. Untuk mengetahui pengaruh dari lembaga keuangan mikro dan pemberdayaan perempuan terhadap tingkat kemiskinan, penelitian ini menggunakan analis PLS SEM. Hasil dari penelitian ini menunjukkan bahwa lembaga keuangan mikro dan pemberdayaan perempuan secara simultan mempengaruhi tingkat kemiskinan. Secara parsial, lembaga keuangan mikro dan pemberdayaan perempuan memberikan dampak yang positif dan signifikan terhadap pengurangan tingkat kemiskinan di Kabupaten Sumedang, khusunya di 5 Kecamatan yaitu Cisitu, Darmaraja, Wado, Jatigede dan Jatinunggal. Dengan melakukan pemberdayaan perempuan melalui pemberian akses yang lebih pada perempuan dengan pemanfaatan kredit mikro akan membantu menambah penghasilan keluarga, khususnya bagi masyarakat OTD.
\end{abstract}

Kata kunci: Lembaga keuangan mikro; kredit mikro; pemberdayaan perempuan; pengentasan kemiskinan

\section{MICROFINANCE INSTITUTION AND WOMAN EMPOWERMENT AS POVERTY ALLEVIATION EFFORT IN SUMEDANG REGENCY}

\begin{abstract}
Microfinance institutions referred to as an institution that can provide facilities for small and micro entrepreneurs in the provision of micro credit to develop businesses and to alleviate poverty. This study aims to determine the effect of microfinance institutions and women's empowerment on poverty levels in Affected People (OTD) in the area around the construction of the Jatigede Dam, Sumedang, West Java, with a population of 10,924 OTD. With a non-probability sampling method with a purposive sampling technique, 100 people were affected by the construction of the Jatigede reservoir spread across five sub-districts in Sumedang, namely Cisitu, Darmaraja, Wado, Jatigede and Jatinunggal. Data collection is done through filling out questionnaires directly with the OTD community. To find out the influence of microfinance institutions and women's empowerment on poverty levels, this study uses PLS SEM analysts. The results of this study indicate that microfinance institutions and women's empowerment simultaneously influence poverty levels. Partially, microfinance institutions and women's empowerment have a positive and significant impact on reducing poverty in Sumedang Regency.
\end{abstract}

Key words: Microfinance institutions; micro credit; woman empowerment; poverty alleviation

\section{PENDAHULUAN}

Kemiskinan masih menjadi salah satu masalah utama yang sedang dihadapi Indonesia pada saat ini. Kemiskinan merupakan implikasi dari beberapa faktor yang bersifat multi dimensial baik sosial-ekonomi, budaya maupun politik (Nugroho, 2001). Berdasarkan data yang diperoleh dari Badan Pusat Statistik Indonesia, jumlah penduduk miskin di Indonesia pada tahun 2016 mencapai $10,70 \%$, dimana angka tersebut mengalami penurunan dari tahun sebelumnya yaitu sebesar $11,25 \%$.

Salah satu daerah yang masih menghadapi masalah kemiskinan di Indonesia adalah Kabupaten Sumedang, Jawa Barat. Berdasarkan data yang diperoleh dari Badan Pusat Statistik Kabupaten Sumedang, tingkat kemiskinan yang terjadi di Kabupaten Sumedang pada tahun 2014 sebesar 10,78\%, kemudian meningkat pada tahun 2015 menjadi 11,36\%, lalu mengalami penurunan pada tahun 2016 menjadi sebesar 10,57\%. Peningkatan tingkat kemiskinan yang terjadi pada tahun 2015 dapat saja terjadi dari beberapa faktor, salah satunya adalah akibat terendamnya pedesaan di sekitar kawasan waduk. Waduk Jatigede ini telah menenggelamkan pemukiman warga sebanyak 28 Desa di 5 kecamatan di Kabupaten Sumedang, termasuk hutan seluas 1.382 hektar dan cagar budaya. Akibatnya sebanyak 10.924 orang terkena dampak dari pembangunan waduk tersebut kehilangan tempat tinggal dan lahan pertanian, sehingga masyarakat kehilangan mata pencahariannya.

Berdasarkan data yang yang diperoleh dari Badan Pusat Statistik Kabupaten Sumedang, tingkat kemiskinan di beberapa kecamatan yang terkena dampak, seperti Kecamatan Darmaraja, pada tahun 2014 sebesar 14,24\%, dan meningkat pada tahun 2016 sebesar 15,66\%, selain itu terdapat empat desa yang dihapuskan karena terendam waduk. Kemudian di Kecamatan Cisitu pada tahun 2014 
tingkat kemiskinan nya sebesar 13,59\% dan pada tahun 2015 sedikit mengalami penurunan menjadi 13,48\%, dan hanya satu desa saja yang dihapuskan.

Salah satu solusi yang dapat dilakukan oleh pemerintah dalam upaya pengentasan kemiskinan tersebut adalah dengan melakukan pemberdayaan pada usaha ibu-ibu rumah tangga karena kaum perempuan pada umumnya selalu berupaya melepaskan diri dari belenggu kesulitan ekonomi dan mengusahakan kehidupan ekonomis yang lebih baik dalam bentuk atau kiat-kiat tertentu dengan memanfaatkan potensi yang dimilikinya secara optimal. Pada salah satu desa yaitu Desa Pakualam terdapat beberapa masyarakat yang membuka usaha nasi liwet dan usaha dagang lainnya, dimana kebanyakan yang mengelola usaha tersebut adalah ibu-ibu rumah tangga yaitu sebanyak 50 orang Ibu Rumah Tangga (IRT). Selain membuka usaha, ibu-ibu juga ada yang menjadi buruh tani dengan data sebanyak 100 orang (Statistik Data Kecamatan Jatigede, 2018).

Oleh karena itu, perlu dilakukannya pemberdayaan perempuan dengan cara mendukung kelompok-kelompok usaha para perempuan terkena dampak tersebut, yaitu dengan membantu usaha ibu-ibu rumah tangga, kelompok wanita tani (KWT), dan kelompok-kelompok usaha lainnya untuk meningkatkan usahanya.

Menurut Basuki dan Prasetyo (2007) perempuan miskin memiliki peran dalam kehidupan keluarganya. Pertama, sebagai pengelola keuangan keluarga. Kedua, sebagai penanggung jawab seluruh pekerjaan domestik. Ketiga, sebagai pencari nafkah keluarga. Keempat, sebagai salah satu simpul jaringan sosial yang penting dalam hal transfer sosial, khususnya pada masa-masa kritis dan krisis.

Namun dalam perkembangannya, usaha kecil memiliki memiliki beberapa kendala terutama keterbatasan modal, kesulitan pemasaran, keterbatasan sumber daya manusia, masalah bahan baku maupun keterbatasan teknologi (Tulus, 2002). Dari beberapa faktor yang disebutkan, yang menjadi faktor kendala yang utama adalah keterbatasan modal yang dimiliki. Hal ini tentunya dapat menghambat perkembangan dari usaha, salah satu solusinya adalah dengan mendapatkan pembiayaan untuk mengembangkan usaha tersebut. Salah satu alternatif dalam upaya pendanaan usaha masyarakat adalah dengan pemberian kredit mikro dari Lembaga Keuangan Mikro (LKM). LKM berfungsi sebagai lembaga keuangan untuk kredit mikro yang merupakan jasa finansial pada skala kecil yang diperuntukan bagi orang-orang yang memiliki keterbatasan akses ke jasa perbankan tradisional, sehingga memberikan kemudahan bagi masyarakat untuk mendapatkan kredit mikro. Program keuangan mikro sendiri telah terbukti dapat membantu dalam upaya pengentasan kemiskinan di Bangladesh, program yang dipelopori oleh Muhammad Yunus melalui Grameen Bank dengan memprioritaskan perempuan sebagai nasabahnya.
Dalam perkembangannya, LKM terbukti dapat mengurangi tingkat kemiskinan melalui meningkatkan pendapatan rumah tangga, meningkatkan peran wanita dalam pembangunan ekonomi (Samer, Majid, Muhamad, Halim, \& Rashid, 2015). Akses ke lembaga keuangan mikro berkontribusi terhadap penurunan kemiskinan, terutama pada partisipasipan perempuan dan penurunan kemiskinan secara keseluruhan pada level desa Khandker (2005). Kemudian penelitian yang dilakukan Nihayah (2015) yang menunjukkan bahwa adanya perubahan yang signifikan terhadap pendapatan sebelum pinjaman dengan pendapatan sesudah pinjaman pada simpan pinjam kelompok perempuan.

Masyarakat perempuan diharapkan mampu meningkatkan akses, kontrol, partisipasi dan kesejahteraan di dalam keluarga maupun kehidupan bermasyarakat (Marwati, 2012). Melalui akses, kontrol dan partisipasi serta kesejahteraan masyarakat perempuan diharapkan dapat membantu meningkatkan penghasilan keluarga. Hal ini tentunya membuka kesempatan bagi masyarakat perempuan dalam berpartisipasi membangun ekonomi pedesaan menjadi lebih baik. Semakin berkembangnya usaha masyarakat, semakin banyak pula pendapatan yang dihasilkan, sehingga dapat digunakan untuk memenuhi kebutuhan hidup standar meliputi pangan, kesehatan, rumah, pendidikan dan kebutuhan transportasi.

Berdasarkan paparan di atas, maka penelitian ini bermaksud untuk mengkaji pengaruh layanan yang diberikan Lembaga Keuangan Mikro dan Program Pemberdayaan Perempuan terhadap pengurangan tingkat kemiskinan pada masyarakat yang terkena dampak dari pembangunan Waduk Jatigede di Sumedang, Jawa Barat.

\section{METODE}

Metode yang digunakan dalam penelitian ini adalah metode deskriptif dan verifikatif. Jenis penelitian yang diterapkan adalah dengan pendekatan kuantitatif melalui metode survei, dimana dilakukan penyebaran kuesioner kepada Orang Terkena Dampak (OTD) yang menjadi sampel penelitian. Proses penyebaran kuesioner dilakukan pada tahun 2018.

Populasi dalam penelitian ini adalah seluruh Orang Terkena Dampak Waduk Jatigede yang berjumlah 10.924. Oleh karena keterbatasan waktu dan biaya, maka tidak semua populasi menjadi responden, sehingga dilakukan proses pengambilan sampel. Umar (2008:59) mengemukakan bahwa untuk menghitung besarnya ukuran sampel dapat dilakukan dengan menggunakan Teknik Slovin dengan perhitungan sebagai berikut:

$$
\begin{aligned}
& n=\frac{10.924}{1+10.924 \times 0,1^{2}} \\
& n=99,09 \approx 100
\end{aligned}
$$

Jadi, jumlah sampel yang digunakan dalam penelitian ini adalah 100 OTD. 
Proses pengambilan sampelnya dilakukan dengan metode non-probability sampling dengan teknik purposive sampling. Menurut Sugiyono (2016:122) purposive sampling adalah teknik penentun sampel berdasarkan kriteria-kriteria atau pertimbangan tertentu. Adapun kriteria yang ditentukan peneliti adalah Orang Terkena Dampak Waduk Jadigede yang tersebar di lima kecamatan yaitu: Jatigede, Jatinunggal, Wado, Darmaraja dan Cisitu, memiliki usaha dalam skala mikro, kecil, dan menengah, pernah atau sedang menggunakan kredit yang diperoleh dari Lembaga keuangan mikro baik formal maupun informal.

Variabel independen dalam penelitian ini adalah lembaga keuangan mikro dan pemberdayaan perempuan, sedangkan variabel dependennya adalah tingkat kemiskinan. Variabel lembaga keuangan mikro akan menggunakan dimensi kemudahan akses, kemudahan layanan, kualitas jasa kredit, dan kehandalan pegawai. Sementara itu variabel pemberdayaan perempuan menggunakan dimensi akses, kontrol, partisipasi, dan kesejahteraan.

Penelitian ini menggunakan analisis PLS SEM dengan SmartPLS versi 3.0 untuk windows. Analisa PLS SEM terdiri dari tiga tahap yakni analisa outer model, analisa inner model dan pengujian hipotesis (Gozali, 2013).

Berdasarkan kajian yang telah dilakukan, kredit mikro yang diberikan oleh Lembaga Keuangan Mikro berpengaruh positif terhadap pengurangan tingkat kemiskinan masyarakat OTD pembangan Jatigede Sumedang dan Pemberdayaan perempuan berpengaruh positif terhadap pengurangan tingkat kemiskinan masyarakat OTD pembangan Jatigede Sumedang. Pernyataan tersebut merupakan dugaan sementara yang harus diuji kebenarannya.

\section{HASIL DAN PEMBAHASAN}

Berdasarkan dari hasil analisis deskriftif, lembaga keuangan mikro yang digunakan oleh masyarakat OTD telah memberikan pelayanan sudah sangat baik dilihat dari sisi waktu pencairan dana, persyaratan, cicilan pinjaman, jumlah pinjaman, suku bunga, cara pembayaran, kemampuan petugas dan respon petugas. lama pinjaman hingga jangka waktu pembayaran. Masyarakat OTD sebagian besar mengakses LKM yang berbentuk formal yaitu KUR dan PNPM Mandiri. Hal ini menunjukkan bahwa LKMLKM tersebut telah menjalankan fungsinya dengan baik khususnya pada layanan kredit mikro.

Begitupun dengan pemberdayaan masyarakat yaitu dengan memprioritaskan masyarakat perempuan sebagai nasabahnya adalah baik dengan melihat sisi akses, kontol, partisipasi dan kesejahteraan. Dengan begitu masyarakat perempuan dapat membantu kebutuhan rumah tangga. Tingkat kemiskinan yang dirasakan para masyarakat OTD masih tergolong tinggi, hal ini disebabkan masih banyak OTD yang terkendala dalam mencukupi pangan, akses terhadap kesehatan, pendidikan rumah dan kebutuhan transportasi.

Berdasarkan analisis verfikatif dengan model SEM dapat dilihat mengenai pengaruh lembaga keuang-an mikro dan pemberdayaan perempuan terhadap tingkat kemiskinan. Variabel lembaga keuangan mikro dan pemberdayaan perempuan secara simultan mempengaruhi variabel tingkat kemiskinan sebanyak 73,9\%. Hal ini berarti 73,9\% pengentasan kemiskinan dipengaruhi oleh adanya lembaga keuangan mikro dengan memberikan pelayanan kredit mikro pada nasabah dengan memprioritaskan perempuan sebagai nasabahnya, sisanya $26,1 \%$ dipengaruhi oleh faktor-faktor lain yang tidak diteliti dalam penelitian ini.

Berikut model struktural yang digunakan dan diolah dengan Smart PLS Versi 3.0 untuk windows:

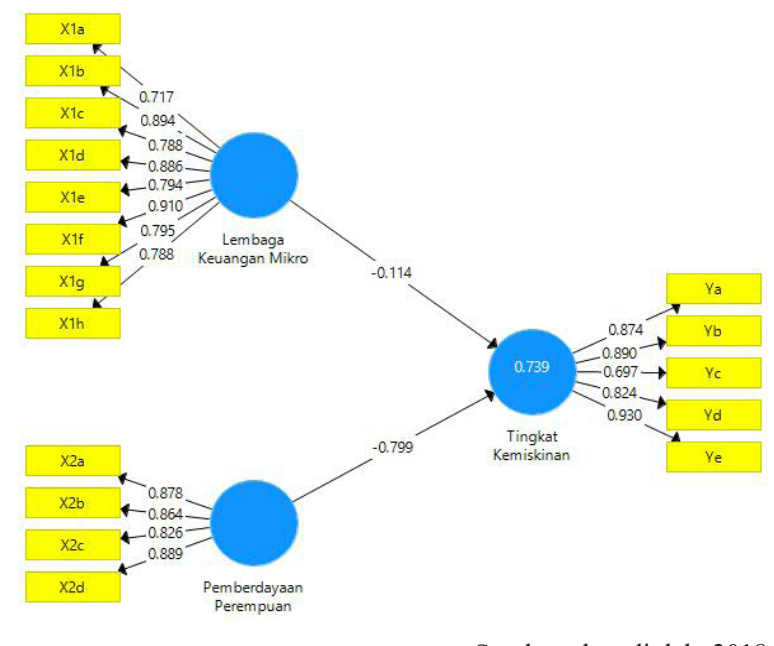

Sumber: data diolah, 2018

Gambar 1. Model Stuktural Smart PLS

Tabel 1 Hasil Uji Hipotesis

\begin{tabular}{llllll}
\hline & $\begin{array}{c}\text { Original } \\
\text { Sample }\end{array}$ & $\begin{array}{c}\text { Sample } \\
\text { Mean }\end{array}$ & $\begin{array}{c}\text { Standard } \\
\text { Deviation }\end{array}$ & $\begin{array}{c}\text { t- } \\
\text { Statistic }\end{array}$ & P-Values \\
\hline LKM $\rightarrow$ & -0.114 & -0.116 & 0.050 & 2.285 & 0.023 \\
KMS & & & & & \\
$\mathrm{PP} \rightarrow$ & -0.799 & -0.802 & 0.043 & 18.806 & 0.000 \\
$\mathrm{KMS}$ & & & & & \\
\hline
\end{tabular}

Sumber: data diolah, 2018

Berdasarkan hasil analisis dengan Smart PLS, Lembaga Keuangan Mikro memiliki arah koefisien yang negatif dan signifikan terhadap tingkat kemiskinan ( $p$-value $<5 \%$ ). Hal ini berarti semakin baik dan fleksibel pelayanan kredit mikro yang diberikan kepada masyarakat OTD, maka semakin banyak pula masyarakat yang tertarik untuk menggunakan kredit mikro, yang mana akan berdampak pada penurunan tingkat kemiskinan bagi masyarakat OTD di Sekitar Waduk Jatigede, khususnya di 5 Kecamatan di Kabupaten Sumedang yakni Cisitu, Darmaraja, Wado, Jatigede dan Jatinunggal. 
Sementara itu, variabel Pemberdayaan perempuan juga memiliki arah koefisien yang negatif dan signifikan terhadap tingkat kemiskinan $((p$-value $<5 \%)$. Artinya, dengan semakin banyaknya pemberian kesempatan pada masyarakat perempuan untuk ikut berpartisipasi dalam kegiatan berwirausaha dan memprioritaskan perempuan sebagai nasabahnya, maka dari usaha yang dijalankan tersebut dapat membantu untuk mencukupi kebutuhan rumah tangga, sehingga dapat menurunkan tingkat kemiskinan masyarakat OTD.

Lebih lanjt, secara simultan variabel Lembaga Keuangan Mikro dan pemberdayaan perempuan mempengaruhi variabel tingkat kemiskinan OTD di daerah sekitar pembangunan waduk Jatigede sebesar 73,9\%, sedangkan $26,1 \%$ dipengaruhi oleh variabel-variabel lainnya yang belum dimasukkan dalam model penelitian.

Hasil penelitian ini sesuai dengan penelitian yang sebelumnya telah dilakukan di Kecamatan Bayat oleh Maika dan Kiswanto (2007) mengenai pemberdayaan perempuan miskin pada usaha kecil di Pedesaan melalui layanan Lembaga Keuangan Mikro dan penelitian yang dilakukan oleh Nihayah (2015) bahwa program simpan pinjam kelompok perempuan dapat memberikan pengaruh positif terhadap pendapatan usaha mikro kecil dan menurunkan tingkat kemiskinan, yang mana dikarenakan adanya perubahan pendapatan sebelum mereka menerima pinjaman dengan pendapatan sesudah mendapatkan pinjaman.

Dengan demikian, dapat dikatakan bahwa Lembaga Keuangan Mikro sebagai salah satu alternatif pembiayaan bagi masyarakat miskin khususnya OTD sangat dibutuhkan dalam rangka pemberdayaan masyarakat khususnya perempuan untuk mendirikan usaha baru ataupun mengembangkan usaha yang telah berjalan. Dengan adanya usaha yang dijalankan oleh masyarakat, maka masyarakat dapat memperoleh penghasilan dan dapat meningkatkan kesejahteraan keluarga yang pada akhirnya dapat menurunkan angka kemiskinan masyarakat khususnya bagi para Orang Terkena Dampak (OTD) di daerah sekitar pembangunan Waduk Jatigede, Sumedang, Jawa Barat.

\section{SIMPULAN}

Layanan kredit mikro yang diberikan oleh Lembaga Keuangan Mikro telah memberikan kemudahankemudahan bagi masyarakat OTD, di Sekitar Waduk Jatigede yaitu dengan memberikan akses pencairan pinjaman yang relatif singkat, memberikan persyaratan yang mudah, memberikan cicilan yang rendah yang mampu dijangkau oleh masyarakat, memberikan jumlah pinjaman yang sesuai kebutuhan masyarakat, membebankan suku bunga yang lebih rendah, sehingga masih terjangkau oleh masyarakat, memberikan cara pembayaran yang relatif mudah serta melayani masyarakat dengan baik dan ramah. Adanya kredit mikro yang disalurkan oleh Lembaga Keuangan Mikro dan Program Pemberdayaan Perempuan dapat memberikan dampak yang positif dan signifikan terhadap pengurangan tingkat kemiskinan di Kabupaten Sumedang, khusunya di 5 Kecamatan yaitu Cisitu, Darmaraja, Wado, Jatigede dan Jatinunggal. Dengan melakukan pemberdayaan perempuan melalui pemberian akses yang lebih pada perempuan dengan pemanfaatan kredit mikro akan membantu menambah penghasilan keluarga, khususnya bagi masyarakat OTD, sehingga tingkat kemiskinan dapat berkurang.

\section{DAFTAR PUSTAKA}

Basuki, A. \& Prasetyo, Y. E. (2007). Memusiumkan Kemiskinan. PATTIRO Surakarta. Surakarta.

Gozali, I. (2006). Structural Equation Modelling: Metode Alternatif dengan Partial Least Square (edisi 2). Semarang: Badan Penerbit Universitas Dipenogoro.

Khandker, S. R. (2005) Microfinance and Poverty: Evidence Using Panel Data from Bangladesh, The World Bank Economic Review, 19, (2), 263-286.

Kiswanto, E. \& Maika, A. (2007). Pemberdayaan Perempuan Miskin Pada Usaha Kecil Di Pedesaan Melalui Layanan Lembaga Keuangan Mikro. Populasi, 18, (1), 0853-0262.

Nihayah, A.Z. (2015). Pengaruh Program Simpan Pinjam Kelompok Perempuan Terhadap Pendapatan Usaha Mikro Kecil dan Poverty Reduction Dalam Perspektif Ekonomi Islam (Studi Kasus PNPM Mandiri Perdesaan Kecamatan Bangilan, Tuban). Economic: Jurnal Ekonomi dan Hukum Islam, 5, (2).

Nugroho, H. (2001). Negara, Pasar, dan Keadilan Sosial (cetakan pertama), Yogyakarta: Pustaka Pelajar.

Samer, Majid, Muhamad, Halim, \& Rashid. (2015). The Impact of Microfinance on Poverty Reduction: Empirical Evidence from Malaysian Perspective. Procedia: Sosial and Behaviour Science, 195, 721-728.

Sugiyono. (2016). Metode Penelitian Kuantitatif, Kualitatif dan $R \& D$. Bandung: Alfabeta. 